\title{
Experimental analysis on the synergistic effect of combined use of ozone and UV radiation for the treatment of dairy industry wastewater
}

\author{
Ramya Suresh $^{1^{\dagger}}$, Baskar Rajoo ${ }^{1^{*}}$, Maheswari Chenniappan ${ }^{2^{*}}$, Manikandan Palanichamy ${ }^{3^{*}}$ \\ ${ }^{1}$ Department of Food Technology, Kongu Engineering College, Perundurai, Erode-638060, Tamilnadu, India \\ ${ }^{2}$ Department of Mechatronics Engineering, Kongu Engineering College, Perundurai, Erode-638060, Tamilnadu, India \\ ${ }^{3}$ Department of chemistry, Kongu Engineering College, Perundurai, Erode-638060, Tamilnadu, India \\ "These authors contributed equally to this work.
}

\section{ABSTRACT}

The present study focused on the various advanced oxidation processes; Ozone, UV radiation, $\mathrm{O}_{3} / \mathrm{H}_{2} \mathrm{O}_{2}, \mathrm{O}_{3} / \mathrm{UV}, \mathrm{UV} / \mathrm{H}_{2} \mathrm{O}_{2}$ and $\mathrm{O}_{3} / \mathrm{UV} / \mathrm{H}_{2} \mathrm{O}_{2}$ for treatability of dairy industry wastewater. With this aim, the trials were carried out in cylindrical reactor fortified with UV radiation and Ozone injection. Efficiency of the treatment process was evaluated considering Chemical Oxygen Demand (COD), lactose reduction and process parameters were determined to be reaction time, $\mathrm{pH}$, circulation rate, and $\mathrm{H}_{2} \mathrm{O}_{2}$ dosage. $32.5 \%, 35.2 \%, 25 \%, 83 \%$ COD and $40.6 \%, 43.6 \%, 38.2 \%, 80 \%$ lactose reduction efficiency were obtained under the operating conditions for $\mathrm{O}_{3} / \mathrm{H}_{2} \mathrm{O}_{2}, \mathrm{O}_{3} / \mathrm{UV}, \mathrm{UV} / \mathrm{H}_{2} \mathrm{O}_{2}$ and $\mathrm{O}_{3} / \mathrm{UV} / \mathrm{H}_{2} \mathrm{O}_{2}$ processes, respectively. As per this outcome, $\mathrm{UV} / \mathrm{H}_{2} \mathrm{O}_{2} / \mathrm{O}_{3}$ process gave more than $65 \%$ of COD and $52.36 \%$ of lactose reduction efficiency than other hybrid processes. Optimum conditions for $\mathrm{UV} / \mathrm{H}_{2} \mathrm{O}_{2} / \mathrm{O}_{3}$ process $\left(\mathrm{pH}=5\right.$, time $=180$ mins, circulation rate $=50 \mathrm{~mL} / \mathrm{h}$ and $\mathrm{H}_{2} \mathrm{O}_{2}$ dosage of $0.5 \mathrm{~mL}$ ) resulted in $88 \%$ of $\mathrm{COD}$ and $93.4 \%$ lactose reduction.

Keywords: Advanced oxidation process, Chemical Oxygen Demand, Dairy industry, Ozone, UV radiation, Wastewater treatment

\section{Introduction}

Among the food industrial sectors, dairy industry consumes more amount of water. Dairy plants include milk processing, butter manufacturing, cheese/whey manufacturing, ice-cream manufacturing and milk powder productions were generating the maximum volume of effluent in a day by day activities [1]. In India, approximately one liter of milk processing produces $10 \mathrm{~L}$ of effluent and it may vary in different countries and dairy plants [2]. Wastewater from these dairy plants composed of carbohydrates, protein, fats, nutrients, sanitizers and detergents [1]. Among these one $\mathrm{kg}$ of protein produces $1.36 \mathrm{~kg}$ of COD, lactose produces $1.13 \mathrm{~kg}$ of COD, fat produces $3 \mathrm{~kg}$ of COD [3]. The pollution load was represented in terms of Biological Oxygen Demand (BOD) (40-48,000 mg/L), Chemical oxygen demand (COD) (80-95,000 mg/L), Total Suspended Solids (TSS) (24-88,000 mg/L) and $\mathrm{pH}$ (4.2-9.4) and its values could be varying with season conditions [4, 5]. Discharging of dairy effluents to water bodies prior to treatment creates various human diseases such as yellow fever, dengue fever, chicken guniya, diahria, lunk cancer and kidney failure etc., [6]. Continuous degradation of casein, lactose and presence of microorganisms create oxygen depletion in receiving water body causes odor, turbidity and eutrophication which was hazardous to fish and algae [5, 7]. The selection and design of proper treatment methods were essential to increase the treatment efficiency of dairy effluent plants [8].

Biological processes such as aerobic and anaerobic, physicochemical processes such as electrocoagulation, membrane process and adsorption were widely used to treat the dairy effluent due to the presence of rich in organic matter [9, 10]. However, the above-mentioned treatment processes produce maximum amount of sludge, periodical maintenance, hydraulic/solid retention time, requirement of pretreatment, cost of electrodes/coagulants/adsorbents, recovery
This is an Open Access article distributed under the terms of the Creative Commons Attribution Non-Commercial License (http://creativecommons.org/licenses/by-nc/3.0/) which permits unrestricted non-commercial use, distribution, and reproduction in any medium, provided the original work is properly cited.

Copyright (C) 2021 Korean Society of Environmental Engineers
Received July 01, 2020 Accepted September 17, 2020

${ }^{\dagger}$ Corresponding author

Email: ramya24591@gmail.com

Tel: +8760382006

ORCID: 0000-0003-0273-2857 
of coagulants/adsorbents, difficulties faced in disposal of sludge, cost of electricity and membrane, periodical replacement of electrode/membrane and toxicity of effluent leads to limitation of the process [11-14]. Although these methods produce considerable results in pollutant removal, its not give complete elimination of pollution load in dairy effluents.

In order to achieve the complete degradation of pollutants, the usage of Advanced Oxidation Methods (AOPs) in dairy wastewater was considerably increasing. In AOP, the generation of highly active chemical species as hydroxyl radicals which has a tendency to react with pollutants and converted into $\mathrm{CO}_{2}$ and $\mathrm{H}_{2} \mathrm{O}[15,16]$. Ozone was one of the AOP, which was directly or indirectly (in the form of secondary radicals) reacts with organic compounds [17]. As the ozone alone in dairy treatment process should not promote complete mineralization of organic compounds. Hence, the efficiency of ozone process was enhanced by the addition of catalytic reactants such as UV radiation, fenton and $\mathrm{H}_{2} \mathrm{O}_{2}$ [18-20]. Nowadays most of the researchers were concentrating on AOP due to the following advantages such as generation of ozone consumes less energy, no sludge production, decrease in volume of sample, less treatment time, gaseous state, easy maintenance, simple and reliable operation which considerably increased the treatment performance of dairy wastewater [18, 19, 21]. In the AOP process, compared to an individual, hybrid processes such as $\mathrm{O}_{3} / \mathrm{H}_{2} \mathrm{O}_{2}, \mathrm{O}_{3} / \mathrm{UV}$ and $\mathrm{UV} / \mathrm{H}_{2} \mathrm{O}_{2}$ processes were mostly used to treat the different industrial wastewater includes hospital, pharmaceutical, winery, olive oil and textile [22]. Although AOP has notable merits, the presence of residual ozone and un-oxidized ozone from the reactor could create harmful effects on the human being. Proper installation of ozone destruction system in wastewater treatment plants considerably reduces the above-mentioned problems [23].

Efficiency of combined AOP process depends upon the buffering conditions of effluent, concentration of pollutants, temperature, Total Solids (TS), TSS, turbidity, COD and BOD load, ozone concentration, ozone diffusion rate and ozone decomposition rate [24, 25]. The combination of AOP with Biological or physicochemical methods superiorly promotes the treatment performance which creates a possible way to achieving zero pollutant discharge. László, Kertész [26], also proved that the pre ozone treatment with nanofiltration greatly increases the biodegradability of dairy wastewater to $96.4 \%$. This was due to the application of preozonation consid- erably reduces the membrane flux that could promote the filtrate properties of membrane [27]. In contrast, when applying a fenton as a post-treatment of membrane process, it does not give possible results in pollutant removal due to the formation of ion compounds during fenton reaction [28, 29].

This present study aims to investigate the performance of synergisation of UV radiation with ozone $/ \mathrm{H}_{2} \mathrm{O}_{2}$ system in simulated and real dairy effluent. The effect of various parameters such as circulation rate, $\mathrm{H}_{2} \mathrm{O}_{2}$ concentration and $\mathrm{pH}$ on pollutant removal interms of BOD, COD, turbidity and color removal were studied. The real dairy industry effluent was treated under the optimum conditions obtained in simulated dairy effluent treatment.

\section{Materials and Methods}

\subsection{Dairy Wastewater and its Characterization}

Real time dairy industrial wastewater was collected from the local industry located in Tamilnadu, India and the samples were collected in accordance with standard methods of sampling. Polyethene cans were properly washed with mild detergent and then leached with 1:1 HCl overnight. The containers were rinsed with deionized water before the sampling at the point of discharge. Two different sets of samples were taken in 1,000 mL bottles initially and then poured into other two different five liter cans for homogenization. All the samples were stored in ice box containing well frozen ice until they were taken to the laboratory.

Similarly, simulated dairy wastewater was prepared by dissolving $4 \mathrm{~g}$ of skimmed milk powder in one liter of distilled water [30-32]. The milk powder used were of commercial grade and used throughout the experiments without further purification in order to represent the actual conditions. Per $100 \mathrm{~g}$ of skimmed milk powder consists $22 \mathrm{~g}$ of protein, $18 \mathrm{~g}$ of fat and $50 \mathrm{~g}$ of carbohydrates. To achieve uniformity throughout the experiment, simulated dairy wastewater was newly prepared before the experimental studies. The prepared simulated dairy wastewater was considered as a representative sample equivalent to the characteristics of real time dairy effluent.

The initial characterization of real and simulated dairy wastewater was characterized as per the standard analytical techniques described by APHA [33] was presented in Table 1.

Table 1. Characterization of Dairy Wastewater

\begin{tabular}{lccccccc}
\hline Parameters & Real effluent 1 & Real effluent 2 & Real effluent 3 & Mean & \multicolumn{2}{c}{ Simulated effluent } \\
pH & 4.58 & 5.25 & 4.44 & 4.76 & 5 & 7 \\
COD (mg/L) & 1,092 & 975 & 1,321 & 1,129 & 1,920 & 2,000 & 2,080 \\
BOD (mg/L) & 194 & 178 & 245 & 206 & 148 & 152 & 165 \\
DO (mg/L) & 7.44 & 6.81 & 9.32 & 7.86 & 7.39 & 7.53 & 7.79 \\
TDS (mg/L) & 9,500 & 3,500 & 7,320 & 6,773 & 2,310 & 1,296 & 1,733 \\
Turbidity (NTU) & 1,630 & 1,390 & 1,870 & 1,630 & 2,051 & 1,734 & 1,675 \\
Color & White & Light white & Slightly dark white & $* * *$ & White & White & White \\
Lactose (mg/L) & 350 & 305 & 420 & 358 & 298 & 300 & 314.52 \\
Conductivity (ms/cm) & 3.78 & 3.24 & 4.05 & 3.69 & 0.5 & 0.26 & 0.3 \\
Chloride (mg/L) & 370 & 360 & 410 & 380 & 237 & 245 & 260 \\
\hline
\end{tabular}




\subsection{Experimental Setup}

The experimental setup for Ozone/UV/ $\mathrm{H}_{2} \mathrm{O}_{2}$ system was shown in Fig. 1. It was divided into five parts: (1) Photo reactor, (2) $\mathrm{H}_{2} \mathrm{O}_{2}$ feed tank, (3) Circulation tank, (4) Ozonator, and (5) Ozone destructor. The photoreactor was made up of glass tube with a diameter of $3 \mathrm{~cm}$ and a length of $20 \mathrm{~cm}$. The photoreactor was equipped with the provision for the insertion of UV lamp (Philips) of $16 \mathrm{~W}$ power supply $254 \mathrm{~nm}$ wavelength at the top of the reactor and ozone gas from the ozonator (Faraday ozone FVP10-136) was introduced from bottom of the reactor through a diffuser at the rate of $800 \mathrm{mg} / \mathrm{h}$. Ozone destructor was used to destruct the unreacted ozone coming out from the reactor. The required quantity of $\mathrm{H}_{2} \mathrm{O}_{2}$ was fed into the reaction chamber from the peroxide tank during circulation of the simulated dairy effluent. A programmable peristaltic pump was used to circulate the dairy wastewater at a different flow rate into the reactor at room temperature. A simulated dairy wastewater sample was drawn at a definite time interval from the reaction chamber to analyze the performance of the system during the course of the treatment process.

In the present study, the treatment efficiency of system was studied by varying operational parameters such as $\mathrm{pH}$ from 5 to $9, \mathrm{H}_{2} \mathrm{O}_{2}$ concentration from 0.5 to $0.15 \mathrm{~mL} / \mathrm{L}$, circulation rate from 50 to $150 \mathrm{~mL} / \mathrm{h}$ at a fixed ozone dosage of $800 \mathrm{mg} / \mathrm{h}$. $\mathrm{pH}$ of the simulated dairy effluent was adjusted using sodium hydroxide and hydrochloric acid. All the experimental trials were carried out in a circulation mode with a sample volume of $160 \mathrm{~mL}$.

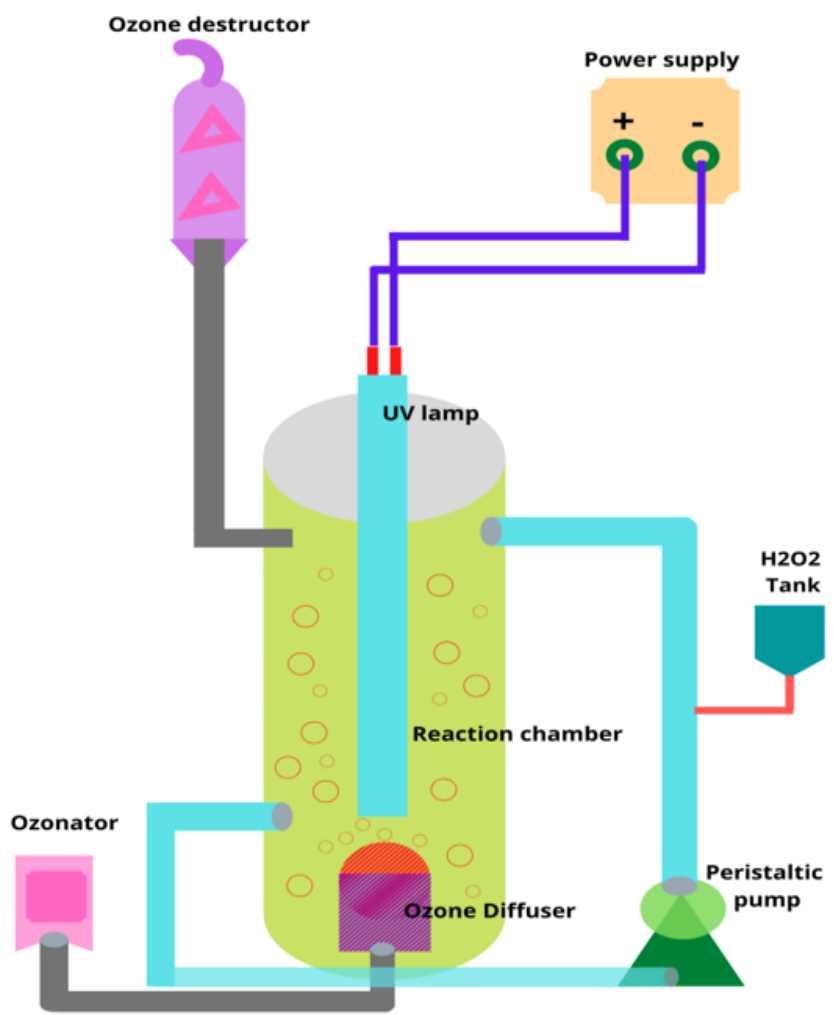

Fig. 1. Experimental setup on ozone based photocatalytic reactor.

\subsection{Analytical Methods and Determination}

The measurable parameters such as $\mathrm{pH}$, conductivity, Chemical Oxygen Demand (COD), Biological Oxygen Demand (BOD), turbidity, Total Dissolved Solids (TDS), turbidity and lactose were measured in dairy wastewater before and after the treatment to ensure removal efficiency of the system. Standard analytical methods were used as per IS 3370 and APHA standards. The $\mathrm{pH}$ and conductivity were measured by using digital $\mathrm{pH}$ meter (Elico LI 120) and conductivity meter (Elico CM 180). Potassium dichromate and sulfuric acid were used to determine the COD. TDS was determined using TDS analyzer (Elico CM 183). Lactose content present in the sample was analyzed spectrophotometrically using Elico CL 223 Colorimeter. Nephelometer (Elico CL 52D) was used to determine the turbidity of the sample. DO meter (Hach HQ430d flexi) was used to analyze BOD present in the dairy effluent.

\section{Results and Discussion}

\section{1. $\mathrm{O}_{3} / \mathrm{H}_{2} \mathrm{O}_{2}, \mathrm{O}_{3} / \mathrm{UV}$ and $\mathrm{UV} / \mathrm{H}_{2} \mathrm{O}_{2}$ System}

The preliminary experimental work was carried out by using advanced oxidation processes such as ozone, UV and $\mathrm{H}_{2} \mathrm{O}_{2}$ either in individual or combination of these processes. From Fig. 2 (a) and (b), when adopting ozone, $\mathrm{UV}$ and $\mathrm{H}_{2} \mathrm{O}_{2}$ process individually, COD and lactose reduction efficiency was less than $10 \%$ which was in agreement with the literature Slavov [34]. However, the combined hybrid process such as $\mathrm{O}_{3} / \mathrm{H}_{2} \mathrm{O}_{2}, \mathrm{O}_{3} / \mathrm{UV}$ and $\mathrm{UV} / \mathrm{H}_{2} \mathrm{O}_{2}$ was carried out at a pH level of 7 and these processes gave notable COD and lactose reduction in dairy wastewater treatment was shown in Fig. 2 (a) and (b).

In $\mathrm{O}_{3} / \mathrm{H}_{2} \mathrm{O}_{2}$ system, addition of $\mathrm{H}_{2} \mathrm{O}_{2}$ in wastewater considerably enhances the COD and lactose reduction of $32.5 \%$ and $40.61 \%$, respectively. When $\mathrm{H}_{2} \mathrm{O}_{2}$ combined with ozone, the ozone was decomposed into $\mathrm{OH}^{*}$ radicals and form a peroxone process in aqueous solution. The $\mathrm{H}_{2} \mathrm{O}_{2}$ was a strong oxidizer having an oxidative potential of $1.78 \mathrm{eV}$ and fastly react with $\mathrm{HO}_{2}^{-}$ions rather than $\mathrm{O}_{3}$ and generates more $\mathrm{OH}^{*}$ radicals as seen in the following reaction [22] (Eq. (1)-(3)).

$$
\begin{aligned}
& \mathrm{H}_{2} \mathrm{O}_{2}+\mathrm{H}_{2} \mathrm{O} \rightarrow \mathrm{HO}_{2}^{-}+\mathrm{H}_{3} \mathrm{O}^{+} \\
& \mathrm{O}_{3}+\mathrm{HO}_{2}^{-} \rightarrow \mathrm{H}_{2} \mathrm{O}+\mathrm{O}_{2}^{-}+\mathrm{O}_{2} \\
& 2 \mathrm{O}_{3}+\mathrm{H}_{2} \mathrm{O}_{2} \rightarrow 2 \mathrm{OH}^{*}+3 \mathrm{O}_{2}
\end{aligned}
$$

It can be seen that the $\mathrm{O}_{3}$ disintegrates into two $\mathrm{OH}^{*}$ radicals which generate more $\mathrm{OH}^{*}$ radicals than ozone alone process with the presence of $\mathrm{H}_{2} \mathrm{O}_{2}$ oxidant. The efficiency of COD and lactose reduction was depended upon the $\mathrm{H}_{2} \mathrm{O}_{2}$ dosage.

In $\mathrm{O}_{3} / \mathrm{UV}$ system, COD of $35.2 \%$ and lactose of $43.68 \%$ reduction was attained during the $3 \mathrm{~h}$ treatment process. When ozone was directly irradiated by UV, a maximum quantity of $\mathrm{OH}^{*}$ radicals were produced than UV or Ozone processes in individuals. As from the following reaction, the photodegradation of $\mathrm{O}_{3}$ molecules 

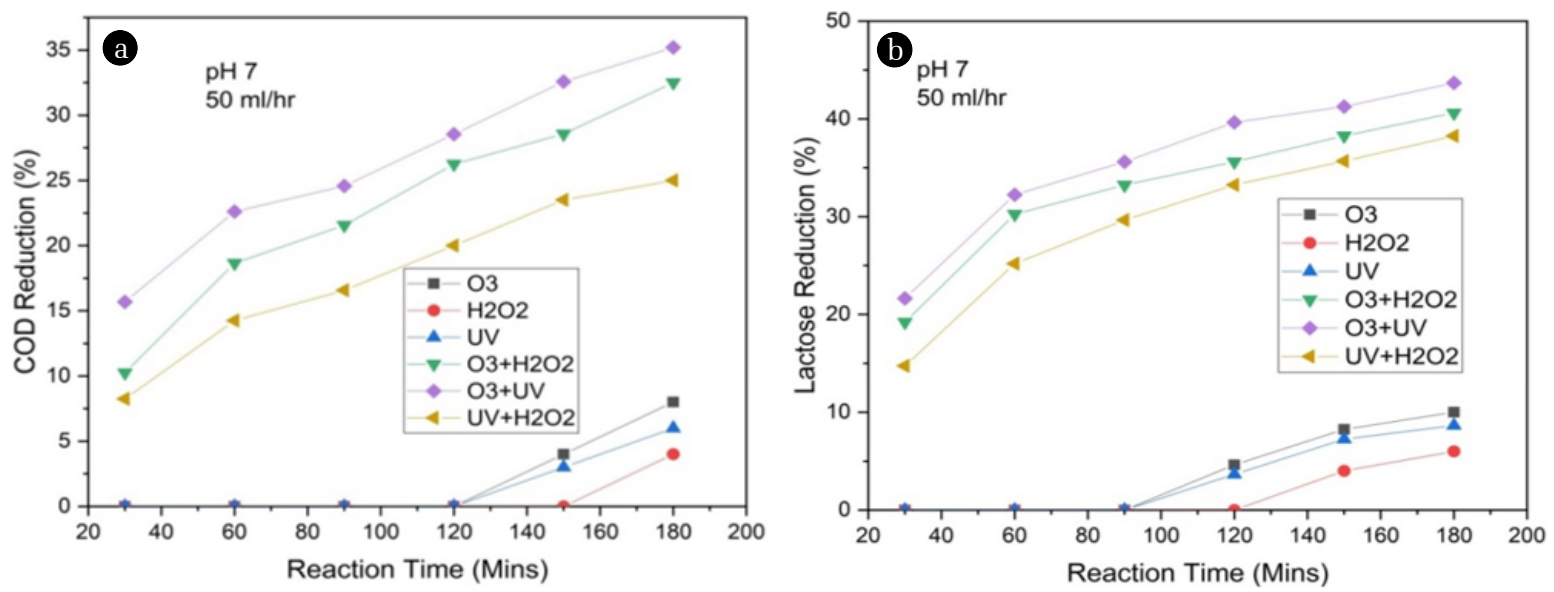

Fig. 2. Synergistic effect of hybrid AOP on COD and lactose reduction.

in water produces $\mathrm{H}_{2} \mathrm{O}_{2}$ and $\mathrm{O}_{2}$ ions further decomposed into $\mathrm{OH}^{*}$ radicals [22] (Eq. (4)-(5)).

$$
\begin{gathered}
\mathrm{O}_{3}+\mathrm{H}_{2} \mathrm{O}+\mathrm{UV} \rightarrow \mathrm{O}_{2}+\mathrm{H}_{2} \mathrm{O}_{2} \\
2 \mathrm{O}_{3}+\mathrm{H}_{2} \mathrm{O}_{2} \rightarrow 2 \mathrm{OH}^{*}+3 \mathrm{O}_{2}
\end{gathered}
$$

$\mathrm{UV} / \mathrm{H}_{2} \mathrm{O}_{2}$ system also gave a considerable result in COD and lactose reduction of $25 \%$ and $38.25 \%$, respectively (Fig. 2 (a) and (b)) which was slightly higher than the $\mathrm{O}_{3} / \mathrm{H}_{2} \mathrm{O}_{2}$ and $\mathrm{O}_{3} / \mathrm{UV}$ system. When $\mathrm{H}_{2} \mathrm{O}_{2}$ was exposed through UV radiation in solution phase, the $\mathrm{OH}^{*}$ radicals were generated in accordance with the following reaction [22] Eq. (6).

$$
\mathrm{H}_{2} \mathrm{O}_{2}+\mathrm{UV} \rightarrow 2 \mathrm{OH}^{*}
$$

As of hybrid processes such as $\mathrm{O}_{3} / \mathrm{H}_{2} \mathrm{O}_{2}, \mathrm{O}_{3} / \mathrm{UV}$ and $\mathrm{UV} / \mathrm{H}_{2} \mathrm{O}_{2}$, the $\mathrm{O}_{3} / \mathrm{UV}$ process gave slightly better results in COD and lactose reduction than other two processes of $\mathrm{O}_{3} / \mathrm{H}_{2} \mathrm{O}_{2}$ and $\mathrm{UV} / \mathrm{H}_{2} \mathrm{O}_{2}$ was proved by Pourgholi, Jahandizi [35].

\section{2. $\mathrm{UV} / \mathrm{H}_{2} \mathrm{O}_{2} / \mathrm{O}_{3}$ System}

During the process, decomposition of $\mathrm{H}_{2} \mathrm{O}_{2}$ produces more secondary species such as exited superoxides, hydrogen peroxide and hydrogen atoms. Although this chemically formed secondary species have a tendency to react with organic matter in the dairy wastewater. The combined use of $\mathrm{UV} / \mathrm{H}_{2} \mathrm{O}_{2} / \mathrm{O}_{3}$ in dairy wastewater enhances the $\mathrm{OH}^{*}$ radicals formation which ultimately increases the COD and lactose reduction. In this present study, $\mathrm{UV} / \mathrm{H}_{2} \mathrm{O}_{2} / \mathrm{O}_{3}$ system was further analyzed at the different operational parameters (circulation rate, reaction time, initial $\mathrm{pH}$ and $\mathrm{H}_{2} \mathrm{O}_{2}$ dosage) and verified with COD and lactose reduction.

It can be explained by the fact that addition of UV and $\mathrm{H}_{2} \mathrm{O}_{2}$ into $\mathrm{O}_{3}$ system greatly enhances degradation efficiency. UV irradiation accelerates the decomposition rate of $\mathrm{O}_{3}$ and $\mathrm{H}_{2} \mathrm{O}_{2}$ into hydroxyl radicals formation by the following chain reaction Eq. (1)-(5).

$$
\mathrm{O}_{3}+\mathrm{H}_{2} \mathrm{O}_{2}+\mathrm{UV} \rightarrow \mathrm{OH}^{*}+\mathrm{O}_{2}+\mathrm{HO}_{2}
$$

$$
\begin{gathered}
\mathrm{O}_{3}+\mathrm{OH}^{*} \rightarrow \mathrm{HO}_{2}^{*}+\mathrm{O}_{2} \\
\mathrm{O}_{3}+\mathrm{HO}_{2}^{-} \rightarrow \mathrm{H}_{2} \mathrm{O}+\mathrm{O}_{2}^{-}+\mathrm{O}_{2}
\end{gathered}
$$

\subsubsection{Effect of $\mathrm{pH}$}

To study effect of solution $\mathrm{pH}$ on the treatment efficiency of the dairy simulated wastewater, the experiments was carried out by adjusting the initial $\mathrm{pH}$ of solution from 5 to 9 .

Effect of $\mathrm{pH}$ on the $\mathrm{COD}$ and lactose reduction of the dairy wastewater by $\mathrm{O}_{3} / \mathrm{UV} / \mathrm{H} 2 \mathrm{O} 2$ process was studied at various $\mathrm{pH}$ ranges of 5, 7 and 9 as illustrated in Fig. 3 (a) and (b). This result shows that the COD and lactose reduction was low in neutral ( $\mathrm{pH}$ 7) and alkaline medium ( $\mathrm{pH}$ 9), and it was protuberant in acidic medium ( $\mathrm{pH}$ 5). During the treatment process, in higher $\mathrm{pH}$ ranges, ozone was continuously oxidized the suspended molecules into dissolved molecules and consequently, ozone demolishes those suspended molecules into small molecules though enhances the COD level in solution [36]. Moreover, decomposition of ozone was quite high at higher $\mathrm{pH}$ ranges (7 to 9) subsequently causes a scavenging effect on the solution than $\mathrm{pH} 5$ [37]. In contrast, in acidic medium ( $\mathrm{pH} \mathrm{5),} \mathrm{ozone} \mathrm{was} \mathrm{directly} \mathrm{influenced} \mathrm{by} \mathrm{the}$ UV radiation and Hydrogen peroxide which was decomposed into $\mathrm{OH}$ radicals enhances the $\mathrm{COD}$ and lactose reduction. The maximum COD and lactose reduction were attained at a $\mathrm{pH}$ value of 5 as $88 \%$ and $93.4 \%$, respectively. On comparing the treatment efficiency of the system on dairy wastewater, lactose reduction was very fast than the COD reduction. About $50.0 \%$ of lactose reduction and $40.0 \%$ of COD reduction was achieved within 30 minutes. Faster and higher lactose removal efficiency and lower and slower COD removal efficiency ensures that fragmentation of lactose takes place initially. But further increase of the COD removal efficiency with time proves the degradation of the fragmentation of bulkier molecules during the reaction.

At different initial $\mathrm{pH}$ values, variation in the $\mathrm{pH}$ value of dairy wastewater during the treatment with respect to the reaction time were shown in Fig. 3 (c). As we clearly have seen in Fig. 3 (c), although we maintain the initial $\mathrm{pH}$ value of wastewater at 5 , 7 and 9, within 30 mins of an interval, solution initial $\mathrm{pH}$ value 

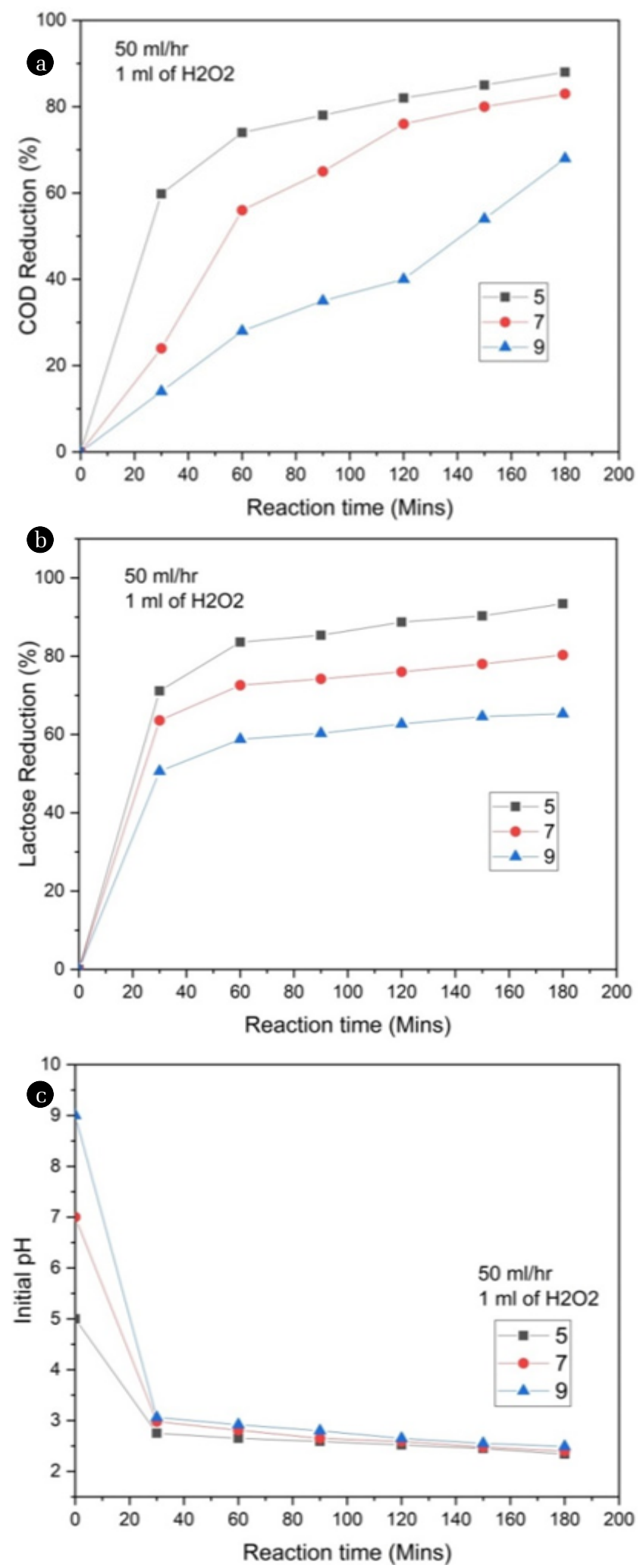

Fig. 3. (a) Effect of $\mathrm{pH}$ on $\mathrm{COD}$ reduction (b) effect of $\mathrm{pH}$ on lactose reduction and (c) Variation of initial $\mathrm{pH}$ levels with respect to reaction time. was dropped between 3.2 to 2.5. This was due to the formation of organic and inorganic acids during the ozone-based photocatalytic process. In dairy wastewater, lactose was one of the major components which undergoes either degradation or fragmentation during the treatment process. Due to this continuous fragmentation of lactose, it was converted into 4-O- $\beta$-galactopyranosyl-D-gluconic acid as shown in Fig. 6 [38]. Although an increase of circulation rate and $\mathrm{H}_{2} \mathrm{O}_{2}$ concentration could not much influence in the variation of $\mathrm{pH}$ ranges. At the end of the treatment process (180 mins), almost $80 \%$ of the lactose was degraded into lactobionic acid. Besides, the increase of treatment time beyond the $3 \mathrm{~h}$ not much influence in the variation of $\mathrm{pH}$ ranges.

Increasing the circulation rate (50 to $150 \mathrm{~mL} / \mathrm{h}$ ) of the wastewater, solution $\mathrm{pH}$ of the wastewater rapidly falls to 2.2 during the treatment process. The same result was observed by maintaining an initial $\mathrm{pH}$ of the solution 7 and 9. But increasing the circulation rate of simulated dairy wastewater, the increased time required to fall of solution $\mathrm{pH}$ during the course of the reaction.

\subsubsection{Effect of circulation rate}

The experimental trials were carried out for the simulated dairy wastewater with the circulation rate of $50-150 \mathrm{~mL} / \mathrm{h}$ at a constant $\mathrm{H}_{2} \mathrm{O}_{2}$ of $1 \mathrm{~mL}$ with different $\mathrm{pH}$ levels were shown in Fig. 4 ((a)-(f)).

As can be seen from the Fig. 4 (a) and (b), at $\mathrm{pH}$ 5, maximum COD and lactose reduction were attained at a minimum circulation rate of $50 \mathrm{~mL} / \mathrm{h}$. Increase of circulation rate from 50 to $150 \mathrm{~mL} / \mathrm{h}$ clearly showed that the decrease of COD and lactose removal efficiency. Similar results were attained at a $\mathrm{pH}$ of 7 and 9 as shown in Fig. 4 ((c), (d), (e) and (f)). On all the pH cases, more than $60 \%$ of COD and $70 \%$ of lactose reduction was attained at a circulation rate of $50 \mathrm{~mL} / \mathrm{h}$ and reaction time of 180 mins. From Fig. 4 (a) and (b), At low circulation rate $(50 \mathrm{~mL} / \mathrm{h})$, the acidic condition ( $\mathrm{pH}$ 5) improves more than 80\% COD and lactose reduction than basic and alkaline conditions of solution within 180 mins. Nevertheless, Fig. 4 ((c), (d), (e) and (f)) reveals that the increase of $\mathrm{pH}$ to basic $(\mathrm{pH}$ 7) and alkaline $(\mathrm{pH} 9)$ condition considerably reduces the COD and lactose reduction about 10 to $15 \%$ compared to acidic condition with the same time and circulation rate. The maximum reduction of COD and lactose reduction was may be achieved at the higher circulation rate even at higher $\mathrm{pH}$ of 7 and 9 by increasing the reaction time beyond the 180 mins.

It could be clearly explained by the fact that the effluent detention time in the photocatalytic reactor of the dairy wastewater was considerably reduced on increasing the circulation rate from 50 to $150 \mathrm{~mL} / \mathrm{h}$. At higher circulation rate, detention time between target molecules and generated oxidative species in the reactor during the treatment process was considerably low which subsequently affects the reduction efficiency of COD and lactose removal. Since the hydroxyl radicals and superoxides were short in life which could not be effectively utilized in the treatment process at the higher circulation rate which could be maximum destruction of oxidative species. Contrariwise, an acquaintance of chemically oxidative species $\left(\mathrm{OH}\right.$ radicals, $\mathrm{O}_{3}$ and $\left.\mathrm{HO}_{2}\right)$ with target molecules of dairy wastewater was maximum at a low circulation rate of $50 \mathrm{~mL} / \mathrm{h}$ which considerably enhances the COD and lactose reduction efficiency. 

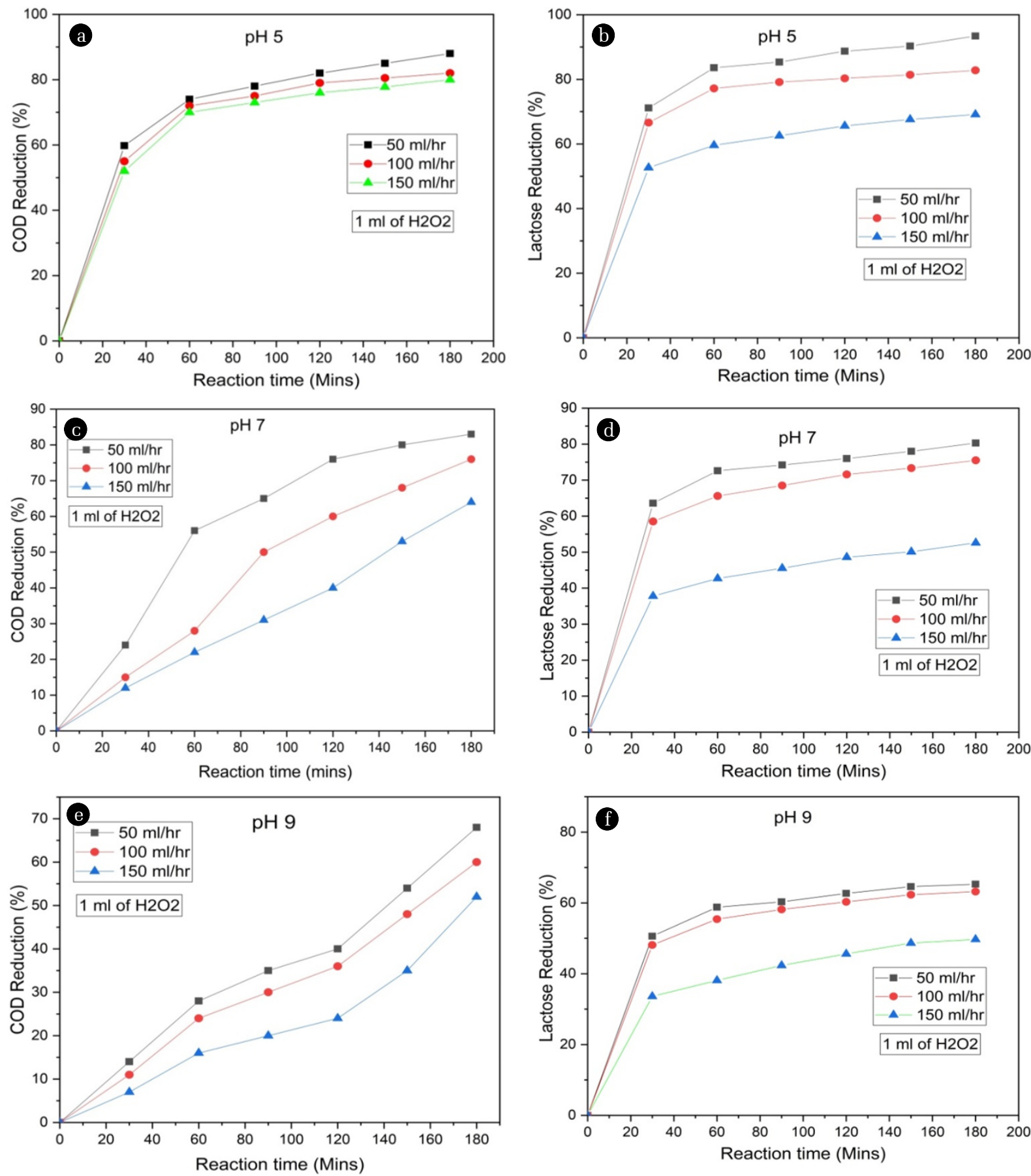

Fig. 4. Effect of circulation rate on the reduction of COD and lactose content.

\subsubsection{Effect of $\mathrm{H}_{2} \mathrm{O}_{2}$ dosage}

During the treatment, the $\mathrm{H}_{2} \mathrm{O}_{2}$ dosage was varied from 0.5 to $1.5 \mathrm{~mL}$ per $100 \mathrm{~mL}$ of dairy wastewater with a constant circulation rate of $100 \mathrm{~mL} / \mathrm{h}$ throughout the process.

Effect of $\mathrm{H}_{2} \mathrm{O}_{2}$ dosage on $\mathrm{COD}$ and lactose reduction with respect to time was illustrated on the Fig. 5. As from Fig. 5 (a) and (b), the result reveals that the increase of $\mathrm{H}_{2} \mathrm{O}_{2}$ dosage from 0.5 to
$1.0 \mathrm{~mL} / \mathrm{h}$ consequently enhances the COD and lactose reduction of $82 \%$ and $77 \%$ respectively at the $\mathrm{pH}$ of 5 . Further increase of $\mathrm{H}_{2} \mathrm{O}_{2}$ dosage to $1.5 \mathrm{~mL}$ decreases the COD and lactose reduction efficiency of $10 \%$ and $11 \%$ from the $\mathrm{H}_{2} \mathrm{O}_{2}$ dosage of $1.0 \mathrm{~mL}$.

Similarly from Fig. 5 ((c), (d), (e) and (f)), the experimental trials were repeated for the dairy effluent with the $\mathrm{pH}$ value of 7 and 9 and the result reveals that the decrease of COD $(<88 \%)$ 

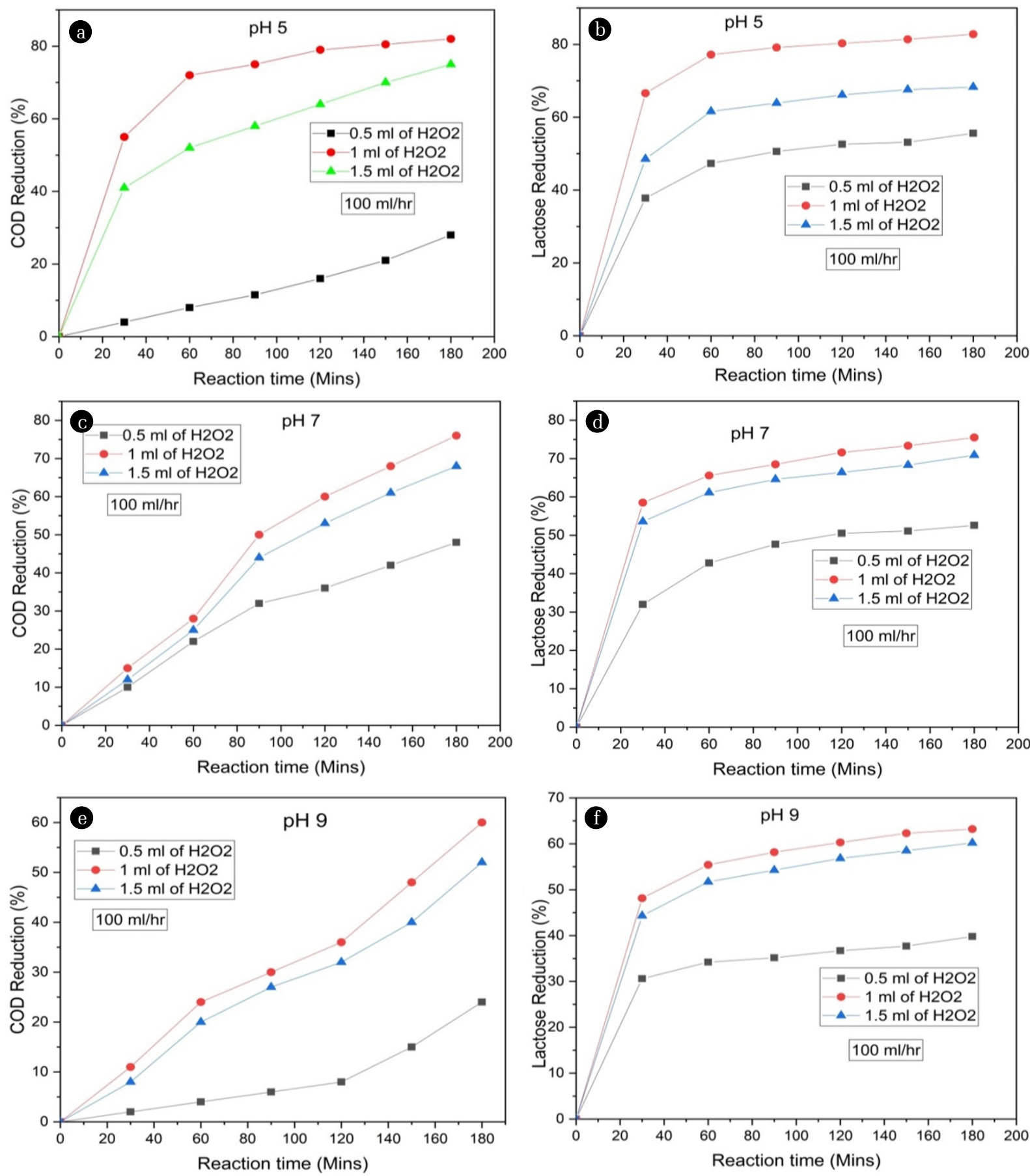

Fig. 5. Effect of $\mathrm{H}_{2} \mathrm{O}_{2}$ concentration on the reduction of COD and lactose content.

and lactose content $(<75 \%)$ by way of increasing $\mathrm{H}_{2} \mathrm{O}_{2}$ dosage from 1.0 to $1.5 \mathrm{~mL} / \mathrm{h}$. From these results, the performance of oxidation process greatly depends upon the formation of the hydroxyl radicals [39].

The supplementary addition of $\mathrm{H}_{2} \mathrm{O}_{2}$ into photocatalytic oxidation also enhances the production of more number of hydroxyl radicals. The lowest COD and lactose reduction efficiency at 0.5
$\mathrm{mL}$ of $\mathrm{H}_{2} \mathrm{O}_{2}$ dosage causes insufficient radical formation during the photocatalytic reaction. Upon increasing the $\mathrm{H}_{2} \mathrm{O}_{2}$ dosage from $1.0 \mathrm{~mL} / \mathrm{h}$ increases the number of reactive radical formation by photochemical synergistic $\mathrm{O}_{3} / \mathrm{UV} / \mathrm{H}_{2} \mathrm{O}_{2}$. Maximum COD and lactose reduction efficiency of $82 \%$ and $82.8 \%$ at the $1.0 \mathrm{~mL} / \mathrm{h}$ of $\mathrm{H}_{2} \mathrm{O}_{2}$ dosage and $\mathrm{pH}$ of 5 , confirms the formation of more number of highly reactive radical formation during the course of the reaction. 
In contrast, a decrease of COD and lactose reduction of $28 \%$ and $55.6 \%$ at the $\mathrm{H}_{2} \mathrm{O}_{2}$ dosage of $1.5 \mathrm{~mL}$ and $\mathrm{pH}$ of 5 . Ineffective utilization of reactive radicals due to the scavenging of hydroxyl radicals during the oxidation process continuously decreases the degradation efficiency of organic matter [40].

This result shows that the lactose and COD reduction ensures that the fragmentation followed by degradation of the organic molecules may take place during the treatment process. Excess amount of $\mathrm{H}_{2} \mathrm{O}_{2}$ in wastewater generates a maximum number of hydroxyl radicals which promotes secondary reactants like hydroperoxide instead of increasing the degradation efficiency of the pollutants. This hydroperoxide was less reactive than hydroxyl radicals was unfavor of organic and inorganic removal. It was concluded that the rate of generation of hydroxyl radicals should be controlled by the dosage of $\mathrm{H}_{2} \mathrm{O}_{2}$.

Based on the $\mathrm{H}_{2} \mathrm{O}_{2}$ dosage on the dairy wastewater, the hydroxyl radicals were formed. At alkaline $\mathrm{pH}$ of 9 the ozone was quickly decomposed and rapidly formed more number of hydroxyl radicals than at pH 5 and 7 [39]. Nevertheless, at a higher dosage of $\mathrm{H}_{2} \mathrm{O}_{2}$, there was a high risk for $\mathrm{H}_{2} \mathrm{O}_{2}$ acted as a radical scavenger which possibly decreases the $\mathrm{OH}^{*}$ radicals concentration in the solution as per the following reaction [22] (Eq. (10)-(11))

$$
\begin{aligned}
\mathrm{OH}^{*}+\mathrm{H}_{2} \mathrm{O}_{2} & \rightarrow \mathrm{OOH}^{*}+\mathrm{H}_{2} \mathrm{O} \\
2 \mathrm{OH}^{*} & \rightarrow \mathrm{H}_{2} \mathrm{O}
\end{aligned}
$$

Lactose was directly related to the COD reduction. During the treatment process, the lactose reacts with hydroxyl radicals and it was partially oxidized into lactobionic acid as a byproduct in COD reduction. The presence of $\mathrm{H}_{2} \mathrm{O}_{2}, \mathrm{OH}^{\circ}, \mathrm{HO}_{2}{ }^{\circ}$ radicals in dairy effluent during the photocatalytic process, continuously reacts with the carbonyl group of lactose and subsequently degraded into 4-O- $\beta$ -galactopyranosyl-D-gluconic acid due to the free radical mechanism as shown in Fig. 6 [38]. During this mechanism, presence of secondary oxygen shown in (Eq-5) could be possible to react with lactobionic acid and finally converted into $\mathrm{H}_{2} \mathrm{O}$.

This could be further supported by Fig. 7 describes that the electrical conductivity and total dissolved solids (TDS) of the wastewater samples were continuously increased during the treatment process. At the initial stage, the conductivity and TDS of wastewater were measured as $0.5 \mathrm{~ms} / \mathrm{cm}$ and $230 \mathrm{ppm}$ respectively and it was continuously increased to $2.9 \mathrm{~ms} / \mathrm{cm}$ and $1,247 \mathrm{ppm}$ respectively. The changes in EC and TDS were explained by the fact that fragmentation of bulkier molecules in the dairy wastewater<smiles>OC[C@H]1O[C@H](O[C@@H]2[C@@H](O)[C@H](O)[C@@H](O)[C@H](O)[C@H]2O)[C@H](O)[C@@H](O)[C@H]1O</smiles>

Lactose

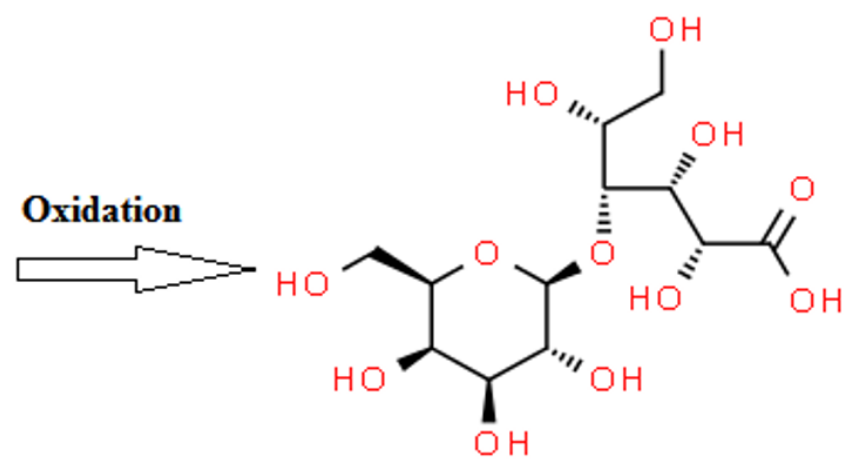

Lactobionic Acid

Fig. 6. Schematic representation of lactose to lactobionic acid conversion.
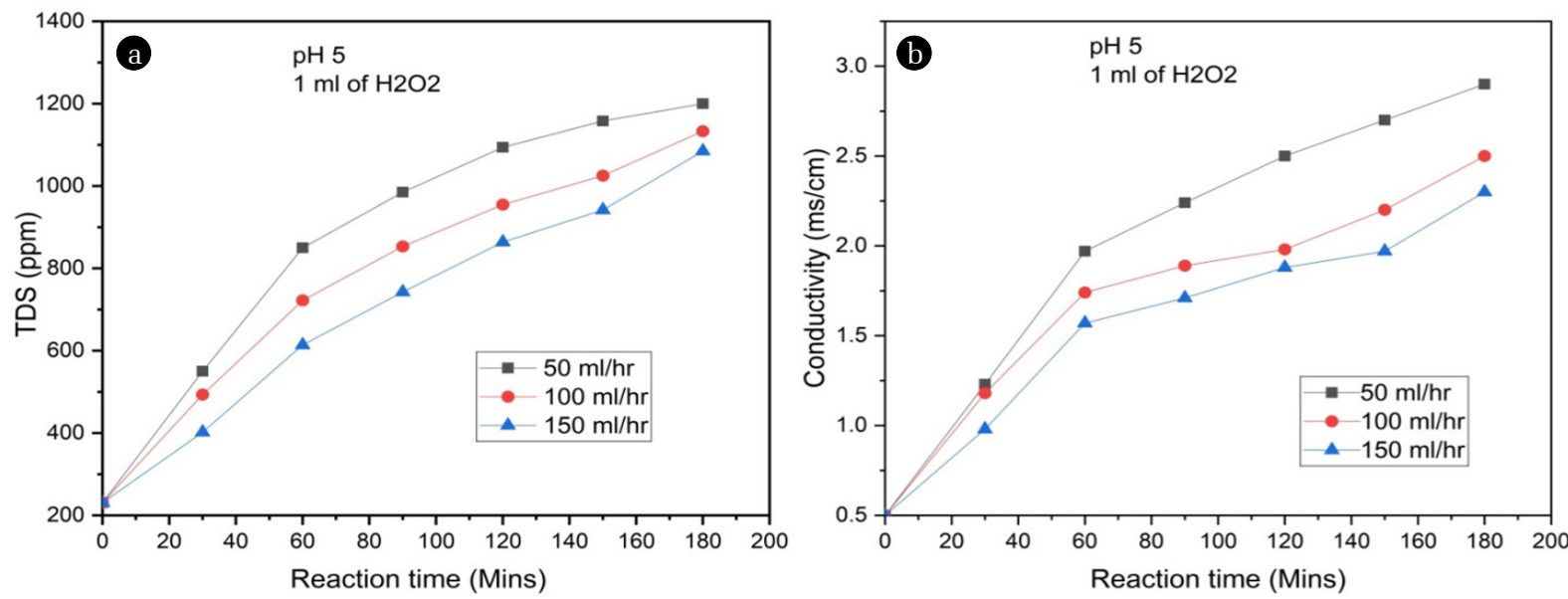

Fig. 7. Variation of TDS and conductivity with respect to circulation rate. 
into smaller ionic species, which may correspondingly, increases the conductivity as well as the TDS.

\subsubsection{Optimum conditions}

From the above sections, the result concluded that the efficiency of COD and lactose reduction was greatly influenced by the initial $\mathrm{pH}$ (5 to 9), circulation rate $(50-150 \mathrm{~mL} / \mathrm{h}), \mathrm{H}_{2} \mathrm{O}_{2}$ dosage (0.5 to $1.5 \mathrm{~mL}$ ) and reaction time (30 to $180 \mathrm{mins}$ ).

Table S1 presents the comparison results of COD reduction on ozone-based photocatalytic process to other treatment processes. Generally, dairy industry wastewater contains organic mater in which most of the researchers were carried out the biological and physicochemical processes. From Table S1, the hybrid AOP process gives more COD reduction in dairy wastewater than other methods. Torres-Sánchez, López-Cervera [41], reveals that the maximum COD reduction of $95 \%$ was achieved when combining the AOP process of ozone and fenton into the electrocoagulation process. The present work exposes that the $\mathrm{O}_{3} / \mathrm{UV} / \mathrm{H}_{2} \mathrm{O}_{2}$ system gave better results in a COD reduction of $88 \%$ compared to other biological and physicochemical processes. In the future, more than $90 \%$ of COD reduction was may be achieved by a combination of the hybrid process of $\mathrm{O}_{3} / \mathrm{UV} / \mathrm{H}_{2} \mathrm{O}_{2}$ and membrane technology.

The synergistic effect of a hybrid process such as $\mathrm{O}_{3}+\mathrm{H}_{2} \mathrm{O}_{2}$, $\mathrm{O}_{3}+\mathrm{UV}, \mathrm{UV}+\mathrm{H}_{2} \mathrm{O}_{2}$ and $\mathrm{O}_{3}+\mathrm{UV}+\mathrm{H}_{2} \mathrm{O}_{2}$ were carried out and its corresponding results were illustrated in Fig. S1 (a) and (b). The hybrid $\mathrm{O}_{3}+\mathrm{UV}+\mathrm{H}_{2} \mathrm{O}_{2}$ process gives the yield of $65 \%$ of $\mathrm{COD}$ and $52.36 \%$ of lactose reduction than other hybrid processes such as $\mathrm{O}_{3}+\mathrm{H}_{2} \mathrm{O}_{2}, \mathrm{O}_{3}+\mathrm{UV}$ and $\mathrm{UV}+\mathrm{H}_{2} \mathrm{O}_{2}$ at the $\mathrm{pH}$ of 7 .

From Fig. S1 (c) and (d), when the treatment time of effluent was increased from 60 to 180 mins, the removal efficiency of COD was increased from 74 to $88 \%$ and lactose conversion was raised from 83.6 to $93.4 \%$ in the $\mathrm{O}_{3}+\mathrm{UV}+\mathrm{H}_{2} \mathrm{O}_{2}$ process. In all the buffering conditions, the acidic medium ( $\mathrm{pH} 5$ ) was found to be more significant on the COD (88\%) and lactose (93.4\%) reduction efficiency. Also, the result reveals that the optimum condition for maximum COD and lactose conversion was taking place at an initial $\mathrm{pH}$ of 5 , circulation rate of $50 \mathrm{~mL} / \mathrm{h}$, reaction time of $180 \mathrm{mins}$ and $\mathrm{H}_{2} \mathrm{O}_{2}$ dosage of $1 \mathrm{~mL}$.

Based on this optimum condition, the performance of $\mathrm{O}_{3} / \mathrm{UV} / \mathrm{H}_{2} \mathrm{O}_{2}$ process was carried out in simulated and real dairy industrial effluent by measuring the parameters such as COD, BOD, lactose, turbidity and color were presented in Table S2.

The maximum removal efficiency of COD, lactose, turbidity and color were attained by 88-92, 97-98, 97-99\% and colorless respectively. During the treatment process, more than $92 \%$ of the biological oxygen demand (BOD) was removed in both simulated and real wastewater which represents the elimination of the maximum amount of microorganisms present in dairy effluent.

\section{Conclusion}

In this research, the synergistic effect of advanced oxidation processes such as ozone, UV radiation; $\mathrm{O}_{3} / \mathrm{H}_{2} \mathrm{O}_{2}, \mathrm{O}_{3} / \mathrm{UV}, \mathrm{UV} / \mathrm{H}_{2} \mathrm{O}_{2}$ and $\mathrm{O}_{3} / \mathrm{UV} / \mathrm{H}_{2} \mathrm{O}_{2}$ for treatability of dairy industry wastewater were studied. Effect of different process variables such as initial $\mathrm{pH}$, reaction time, circulation rate and $\mathrm{H}_{2} \mathrm{O}_{2}$ dosage was observed. This study exposed that $\mathrm{O}_{3} / \mathrm{UV} / \mathrm{H}_{2} \mathrm{O}_{2}$ system can be a better marginal to other hybrid AOP processes and conventional methods when worked under ideal circumstances.

When conducting experiments with individual processes such as ozone, UV radiation and $\mathrm{H}_{2} \mathrm{O}_{2}$, there were no noticeable results $(<10 \%)$ that were found in COD and lactose reduction. COD of $32.5 \%, 35.2 \%, 25 \%, 83 \%$ and lactose of $43.6 \%, 38.2 \%$, $80 \%$ reduction efficiency were attained during the hybrid AOP process of $\mathrm{O}_{3} / \mathrm{H}_{2} \mathrm{O}_{2}$, $\mathrm{O}_{3} / \mathrm{UV}, \mathrm{UV} / \mathrm{H}_{2} \mathrm{O}_{2}$ and $\mathrm{O}_{3} / \mathrm{UV} / \mathrm{H}_{2} \mathrm{O}_{2}$ processes at a $\mathrm{pH}$ of 7 and circulation rate of $50 \mathrm{~mL} / \mathrm{h}$, respectively. From these results, the hybrid $\mathrm{O}_{3} / \mathrm{UV} / \mathrm{H}_{2} \mathrm{O}_{2}$ process was attained maximum COD, lactose reduction of $88 \%$ and $93.4 \%$ respectively under the optimum conditions of $\mathrm{pH}$ of 5 , reaction time of $180 \mathrm{mins}$, circulation rate of $50 \mathrm{~mL} / \mathrm{h}$ and $\mathrm{H}_{2} \mathrm{O}_{2}$ dosage of $1.5 \mathrm{~mL}$. Reduction efficiency of COD and lactose decreased by an increase in $\mathrm{H}_{2} \mathrm{O}_{2}$ dosage of $1.5 \mathrm{~mL}$, initial $\mathrm{pH}$ of 9 and circulation rate of $150 \mathrm{~mL} / \mathrm{h}$. This is due to at an alkaline $\mathrm{pH}$ and higher dosage of $\mathrm{H} 2 \mathrm{O} 2$, the ozone decomposition rate was higher eventually causes a scavenging effect while at maximum circulation rate lack of retention time between radicals and pollutants eventually decreases the COD and lactose reduction efficiency.

However, after the $\mathrm{O}_{3} / \mathrm{UV} / \mathrm{H}_{2} \mathrm{O}_{2}$ treatment process, TDS and EC of treated wastewater were increased to $1,043 \mathrm{ppm}$ and $2.5 \mathrm{~ms}$ from its initial level ensures the incomplete/ partial degradation of organic pollutants present in the dairy effluent. As of this optimum process/conditions, the real dairy effluent was treated while the final concentrations of COD of $105 \mathrm{mg} / \mathrm{lit}, \mathrm{BOD}$ of $18 \mathrm{mg} / \mathrm{lit}$, lactose of $13 \mathrm{mg} / \mathrm{L}$ were achieved.

Removal efficiency of BOD in real-time dairy effluent satisfies the effluent standards recommended by the Central Pollution Control Board (CPCB) of India. However, TDS and $\mathrm{pH}$ of treated effluent did not meet the permissible limits of standards, which need further treatment process before the effluent was to be discharged into receiving bodies.

\section{Acknowledgments}

We acknowledge that this research work was funded by All India Council for Technical Education (AICTE) - Research Promotion Scheme (RPS), the government of India (order no: 8-208/RIFD/RPS (POLICY-1)/ 2018-19).

\section{Authors Contribution}

S.R. (Ph.D student) perceived the research data and wrote the manuscript. R.B. (Professor) administered the project. C.M. (Associate Professor) wrote and look over the manuscript. P.M. (Assistant Professor) assisted in wrote and manage the work.

\section{References}

1. Alimoradi S, Faraj R, Torabian A. Effects of residual aluminum on hybrid membrane bioreactor (Coagulation-MBR) performance, treating dairy wastewater. Chem. Eng. Process. 2018;133: 320-324. 
2. Tiwari S, Behera CR, Srinivasan B. Simulation and experimental studies to enhance water reuse and reclamation in India's largest dairy industry. J. Environ. Chem. Eng. 2016;4:605-616.

3. Jaganmai G, Jinka R. Production of Lipases from Dairy Industry Wastes and its Applications. Int. J. Curr. Microbiol. Appl. Sci. 2017;5:67-73.

4. Suman A, Ahmad T, Ahmad K. Dairy wastewater treatment using water treatment sludge as coagulant: a novel treatment approach. Environ. Dev. Sustainability. 2018;20:1615-1625.

5. Falahati F, Baghdadi M, Aminzadeh B. Treatment of dairy wastewater by graphene oxide nanoadsorbent and sludge separation, using In Situ Sludge Magnetic Impregnation (ISSMI). Pollution. 2018;4:29-41.

6. Subramani T, Rajkumar V, Priyanka S. Treatment Of Dairy Waste Water From Salem. In. J. Appli. Innov. Eng. 2017;6: 263-273.

7. Mejía-Morales C, Hernández-Aldana F, Cortés-Hernández DM, Rivera-Tapia JA, Castañeda-Antonio D, Bonilla N. Assessment of Biological and Persistent Organic Compounds in Hospital Wastewater After Advanced Oxidation Process UV/H2O2/O3. Water Air Soil Pollut. 2020;231:89.

8. Brião VB, Vieira Salla AC, Miorando T, Hemkemeier M, Cadore Favaretto DP. Water recovery from dairy rinse water by reverse osmosis: Giving value to water and milk solids. Resour. Conserv. Recycl. 2019;140:313-323.

9. Labbé JI, Ramos-Suárez Ј, Hernández-Pérez A, Baeza A, Hansen F. Microalgae growth in polluted effluents from the dairy industry for biomass production and phytoremediation. J. Environ. Chem. Eng. 2017;5:635-643.

10. Kolev Slavov A. General characteristics and treatment possibilities of dairy wastewater-A review. Food technol. biotech. 2017;55:14-28.

11. Tawfik A, Sobhey M, Badawy M. Treatment of a combined dairy and domestic wastewater in an up-flow anaerobic sludge blanket (UASB) reactor followed by activated sludge (AS system). Desalination 2008;227:167-177.

12. Martín-Rilo S, Coimbra RN, Martín-Villacorta J, Otero M. Treatment of dairy industry wastewater by oxygen injection: performance and outlay parameters from the full scale implementation. J. Clean. Prod. 2015;86:15-23.

13. Markou V, Kontogianni MC, Frontistis Z, Tekerlekopoulou AG, Katsaounis A, Vayenas D. Electrochemical treatment of biologically pre-treated dairy wastewater using dimensionally stable anodes. J. Environ. Manage. 2017;202:217-224.

14. Bassala HD, Kenne Dedzo G, Njine Bememba CB, et al. Investigation of the efficiency of a designed electrocoagulation reactor: Application for dairy effluent treatment. Process Saf. Environ. Prot. 2017;111:122-127.

15. Tetteh EK, Naidoo DB, Rathilal S. Optimization of photo-catalytic degradation of oil refinery wastewater using Box-Behnken design. Environ. Eng. Res. 2019;24:711-717.

16. Loures CCA, Samanamud GRL, de Freitas A, Oliveira IS, de Freitas LV, Almeida C. The use of Advanced Oxidation Processes (AOPs) in dairy effluent treatment. American J. Theo. Appl. Statis. 2014;3:42-46.

17. dos Santos Pereira M, Borges AC, Heleno FF, Faroni LRDA, da Silva JCGE. Experimental Design Optimization of Dairy
Wastewater Ozonation Treatment. Water Air Soil Pollut. 2018;229:74.

18. Krzemińska D, Neczaj E, Borowski G. Advanced oxidation processes for food industrial wastewater decontamination. J. Ecol. Eng. 2015;16:61-71.

19. Bruguera-Casamada C, Araujo RM, Brillas E, Sirés I. Advantages of electro-Fenton over electrocoagulation for disinfection of dairy wastewater. Chem. Eng. J. 2019;376:119975.

20. Bilińska L, Gmurek M, Ledakowicz S. Textile wastewater treatment by AOPs for brine reuse. Process Saf. Environ. Prot. 2017;109:420-428.

21. Assalin MR, Almeida ES, Rosa MA, Moraes SG, Duran N. Application of ozonation process in industrial wastewaters: textile, kraft E1 and whey effluents. Environ. Technol. 2014;25: 867-872.

22. Karat I. Advanced Oxidation Processes for removal of COD from pulp and paper mill effluents: A Technical, Economical and Environmental Evaluation [dissertation]. Stockholm: KTH Royal Institute of Technology; 2013.

23. Varga L, Szigeti J. Use of ozone in the dairy industry: A review. Int. J. Dairy Technol. 2016;69:157-168.

24. Carvalho MCS, Borges AC, Pereira MdS, Heleno FF, Faroni LRD, Campos LC. Combined use of O3/H2O2 and O3/Mn2+ in flotation of dairy wastewater. Revist. Ambiente Água. 2018;13.

25. Satoab K, Saito T. A newly developed wastewater treatment by using solidification reaction of milk fats and proteins through ozonation. Chem. Eng. Trans. 2013;32:1-6.

26. László Z, Kertész S, Mlinkovics E, Hodúr C. Dairy Waste Water Treatment by Combining Ozonation and Nanofiltration. Sep. Sci. Technol. 2007;42:1627-1637.

27. Zakar M, Kovács I, Muhi P, Lakatos EH, Keszthelyi-Szabó G, László Z. The Effect of Advanced Oxidation Pre-Treatment on the Membrane Filtration Parameters of Dairy Wastewater. Hung. J. Ind. Chem. 2017;45:23-27.

28. Stanisławek E, Kowalik-Klimczak A. Integration of advanced oxidation process with nanofiltration for dairy effluent treatment. Chall. Mod. Technol. 2017;8:3-6.

29. Melo JMO, Duarte JLS, Ferro AB, Meili L, Zanta CLPS. Comparing Electrochemical and Fenton-Based Processes for Aquaculture Biocide Degradation. Water Air Soil Pollut. 2020;231:79.

30. Leal MCMR, Freire DMG, Cammarota MC, Sant'Anna GL. Effect of enzymatic hydrolysis on anaerobic treatment of dairy wastewater. Process. Biochem. 2006;41:1173-1178.

31. Loloei M, Nekonam G, Alidadi H, Kor Y. Study of the coagulation process in wastewater treatment of dairy industries. Int. J. Environ. Health. Eng. 2014;3:12.

32. Benazzi TL, Di Luccio M, Dallago RM, Steffens J, Mores R, Do Nascimento MS, Krebs J, Ceni G. Continuous flow electrocoagulation in the treatment of wastewater from dairy industries. Water. Sci. Technol. 2016;73:1418-1425.

33. APHA. Standard Methods For Examination of Water and Wastewater. WWA, Washington, DC. 2005.

34. Slavov AK. General Characteristics and Treatment Possibilities ofDairy Wastewater - A Review. Food Technol. Biotechnol. 2017;55:14-28.

35. Pourgholi M, Jahandizi RM, Miranzadeh M, Beigi OH, Dehghan S. Removal of Dye and COD from textile wastewater using 
AOP (UV/O3, UV/H2O2, O3/H2O2 and UV/H2O2/O3). J. Environ. Health Sustain. Dev. 2018:621-629.

36. Yasar A, Ahmad N, Chaudhry M, Rehman M, Khan A. Ozone for Color and COD Removal of Raw and Anaerobically Biotreated Combined Industrial Wastewater. Polish J. Environ. Studies. 2007;16.

37. Manikandan P, Palanisamy PN, Baskar R, Sivakumar P, Sakthisharmila P. Optimization of treatment efficiency of UV/H2O2 process on simulated textile industry wastewater. Desalin. Water. Treat. 2016;57:27169-27180.

38. Belkacemi K, Hamoudi S. Chemocatalytic Oxidation of Lactose to Lactobionic Acid over Pd-Bi/SBA15: Reaction Kinetics and Modeling. Ind. Eng. Chem. Res. 2010;49:6878-6889.

39. Abreu P, Pereira E, Campos CM, Naves F. Photocatalytic Oxidation Process (UV/H2O2/ZnO) in the treatment and sterilization of dairy wastewater. Acta. Sci. Technol. 2013;35:75-81.

40. Lucas M, Peres J, Puma G. Treatment of winery wastewater by ozone-based advanced oxidation processes $(\mathrm{O} 3, \mathrm{O} 3 / \mathrm{UV}$ and O3/UV/H2O2) in a pilot-scale bubble column reactor and process economics. Sep. Purif. Technol. 2010;72:235-241.

41. Torres-Sánchez AL, López-Cervera SJ, de la Rosa C, Maldonado-Vega M, Maldonado-Santoyo M, Peralta-Hernández
JM. Electrocoagulation process coupled with advance oxidation techniques to treatment of dairy industry wastewater. Int. J. Electrochem. Sci. 2014;9:6103-6112.

42. Kothari R, Kumar V, Pathak VV, Tyagi VV. Sequential hydrogen and methane production with simultaneous treatment of dairy industry wastewater: Bioenergy profit approach. Int. J. Hydrog. Energy. 2017;42:4870-4879.

43. Bhuyar KD, Suke SG, Dawande S. Treatment of milk wastewater using up-flow anaerobic packed bed reactor. Pol. J. Chem. Technol. 2015;17:84-88.

44. Al-Jabari M, Dwiek H, Zahdeh N, Eqefan N. Reducing Organic Pollution of Wastewater from Milk Processing Industry by Adsorption on Marlstone Particles. Int. J. Thermal Environ. Eng. 2017;15:57-61.

45. Martins RC, Quinta-Ferreira RM. Final remediation of post-biological treated milk whey wastewater by ozone. Int. J. Chem. React. Eng. 2010;8.

46. Sivrioglu O, Yonar T. Determination of the acute toxicities of physicochemical pretreatment and advanced oxidation processes applied to dairy effluents on activated sludge. J. Dairy Sci. 2015;98:2337-2244. 